\title{
A Review of Surface Treatment Methods to Improve the Adhesive Cementation of Zirconia-Based Ceramics
}

\author{
Rodrigo Dalla Lana Mattiello, ${ }^{1}$ Tulio Marcos Kalife Coelho, ${ }^{1}$ Elizeu Insaurralde, \\ Alan Augusto Kalife Coelho, ${ }^{2}$ Gustavo Pereira Terra, ${ }^{3}$ Amanda Vessoni Barbosa Kasuya, ${ }^{4}$ \\ Isabella Negro Favarão, ${ }^{4}$ Luciano de Souza Gonçalves, ${ }^{5}$ and Rodrigo Borges Fonseca ${ }^{4,6}$ \\ ${ }^{1}$ Occlusion and Fixed Prosthodontics Department, Dental School, UFMS, Campo Grande, MS, Brazil \\ ${ }^{2}$ Department of Periodontics, Dental School, UFMS, Campo Grande, MS, Brazil \\ ${ }^{3}$ Department of Implantology, Dental School, UFMS, Campo Grande, MS, Brazil \\ ${ }^{4}$ Department of Restorative Dentistry and Dental Materials, Dental School, UFG, Goiânia, GO, Brazil \\ ${ }^{5}$ Department of Dental Materials, Dental School, UNIUBE, Uberaba, MG, Brazil \\ ${ }^{6}$ Faculdade de Odontologia, Universidade Federal de Goiás, Praça Universitária Esquina com $1^{a}$ Avenida s/n, \\ Setor Universitário, 74605-220 Goiânia, GO, Brazil
}

Correspondence should be addressed to Rodrigo Borges Fonseca; rbfonseca.ufg@gmail.com

Received 17 July 2013; Accepted 29 August 2013

Academic Editors: A. Apicella, S.-J. Ding, R. Marx, and S. Sauro

Copyright (c) 2013 Rodrigo Dalla Lana Mattiello et al. This is an open access article distributed under the Creative Commons Attribution License, which permits unrestricted use, distribution, and reproduction in any medium, provided the original work is properly cited.

In spite of high mechanical strength, zirconia-based ceramics $\left(\mathrm{ZrO}_{2}\right)$ has poor bond strength after conventional bond cementation procedures, requiring different surface treatment methods (STMs). This review gathered information about the STM for adhesive cementation (AC) to $\mathrm{ZrO}_{2}$ in the PubMed database, considering in vitro studies pertaining to AC for acid-resistant ceramics $\left(\mathrm{ZrO}_{2}\right)$ limited to peer-reviewed papers published in English between 1965 and 2013 in dental journals. Different STMs have been proposed for $\mathrm{ZrO}_{2}$ : air-abrasion (laboratory or chairside) with silica- (Si-) coated aluminum particles, the use of materials containing phosphate monomers, primer or silane application, laser irradiation, Si vapor phase deposition, and selective infiltration etching. In conclusion, STMs improve bond strength of resin luting cement to $\mathrm{ZrO}_{2}$ mainly when tested in short time. STMs must be correlated to the type of $\mathrm{ZrO}_{2}$ and the resin cement.

\section{Introduction}

Recent developments in ceramic materials science for dental applications have led to a class of high fracture strength materials represented by alumina $\left(\mathrm{Al}_{2} \mathrm{O}_{3}\right)$ and zirconia-based ceramics $\left(\mathrm{ZrO}_{2}\right)$ that potentially enable long-term durability $[1,2]$. These improved properties allowed the use of allceramic materials in situations of high mechanical stress, such as framework materials, crowns, bridges, core, and post systems [3].

The increase of mechanical properties by $\mathrm{ZrO}_{2}$ addition is accompanied by a reduction in the glassy matrix and $\mathrm{Si}$ content $[3,4]$ resulting in acid-resistant ceramics [5]. In the Si-based ceramics the glassy matrix is selectively removed by hydrofluoric acid (HF) etching, increasing the surface roughness (Ra) for micromechanical bonding [6-8]. This procedure is generally followed by application of a silane coupling agent, that is able to bond with the silicone dioxide $\left(\mathrm{SiO}_{2}\right)$ and copolymerizes with the organic matrix of the resin cement [2]. The lack of a glassy matrix and the absence of $\mathrm{SiO}_{2}$ make acid etching plus silane application incapable of modifying and treating the zirconia surface [9-12], with no apparent improvement in bond strength $[7,8,13]$.

The clinical success of ceramic restorations depends on the cementation process [7]. Adhesive cementation (AC) to $\mathrm{ZrO}_{2}$ ceramics is desirable [14] since it improves retention [2, 15], marginal adaptation, and fracture resistance [16], reduces the possibility of recurrent decay $[8,17]$, and enables more conservative cavity preparations [15]. Different methods to 
TABLE 1: Criteria for paper selection for this study.

\begin{tabular}{ll}
\hline Topics & Criteria \\
\hline Database & PubMed \\
Date range & 1965 to 2013 \\
& Ceramic surface treatment AND \\
Keywords & zirconia, \\
& "zirconia adhesion," zirconia ceramics, \\
and "bond strength" & English \\
Language & $\begin{array}{l}\text { In vitro laboratory research and literature } \\
\text { Type of paper }\end{array}$ \\
Subset (journal group) & Dental journals \\
\hline
\end{tabular}

TABLE 2: Number of selected papers according to keywords.

\begin{tabular}{lccc}
\hline Keywords & $\begin{array}{c}\text { Total retrieved } \\
\text { papers }\end{array}$ & $\begin{array}{c}\text { Number of } \\
\text { selected papers }\end{array}$ & Total $^{*}$ \\
\hline $\begin{array}{l}\text { Ceramic surface } \\
\text { treatment and zirconia }\end{array}$ & 120 & 30 & 79 \\
"Zirconia adhesion" & 79 & 12 & \\
$\begin{array}{l}\text { Zirconia ceramics and } \\
\text { "bond strength" }\end{array}$ & 118 & 37 & \\
\hline
\end{tabular}

*Excluding repeated papers.

promote the adequate adhesion between the resin cement and $\mathrm{ZrO}_{2}$ have been proposed: use of a phosphate-modified monomer (MDP) in resin cement [2, 18-23], laboratory or chairside air-abrasion with 110 and $30 \mu \mathrm{m}$ Si-coated aluminum particles [22-26], the use of zirconate coupler primers [27], tetraethoxysilane flame-treat device usage [3], the use of organofunctional silanes [28, 29], laser irradiation $[17,30]$, the Si vapor phase deposition method [1], and the selective infiltration etching procedure [31-33].

Nevertheless, even with all these surface treatment methods (STMs) for increasing bond strength to $\mathrm{ZrO}_{2}$ there are several controversial results, especially due to different bond strength testing methodologies [3]. The aim of this study was to discuss the STM for increasing adhesion capability of $\mathrm{ZrO}_{2}$ by means of reviewing the literature, establishing a protocol for clinical procedures.

\section{Methods}

This review of the literature was based on a PubMed databases search following the criteria listed in Table 1. Papers were selected since 1965 due to the first cited method to strengthen dental ceramics by the addition of reinforcement oxides [34]. However, since it was not the aim of the present work to identify $\mathrm{ZrO}_{2}$ ceramics introduction and development into dentistry, the search was limited to find different STMs and their results in relation to bond strength.

\section{Results}

The number of papers retrieved and selected from the PubMed search are described in Table 2. From all retrieved papers (Table 2) the ones that described techniques developed to increase bond strength of $\mathrm{ZrO}_{2}$ to resin cement and their relation with the material's composition were selected. Bond strength methods of selected papers were shear tests (29 papers), microshear tests (3 papers), tensile tests (5 papers), microtensile tests (11 papers), and pull-out tests (01 paper). Just one paper employed both micro-tensile and shear bond strength methods, observing similar results [35].

Table 3 shows retrieved papers from PubMed database search grouped in accordance with bond strength (BS) tests, surface treatment method (STM), and results for BS improvement. Only zirconia-based ceramics BS measurements were listed in the table.

The following sections are based on the types of STMs for $\mathrm{ZrO}_{2}$. Treatments were divided into chemical surface treatments, mechanical surface treatments, and alternative treatments.

\section{Chemical Surface Treatments}

4.1. Hydrofluoric Acid Etching. The most common STM for AC to ceramic restorations is based either on micromechanical bond obtained with HF etching, particles sandblasting or on chemical bond, obtained by the application of a silane coupling agent [15]. HF removes the glassy matrix of glass ceramics creating a high surface energy substrate with microporosities for the penetration and polymerization of resin composites, that is, enabling a micromechanical interlocking [7]. However, HF etching does not produce any change in arithmetic roughness $(\mathrm{Ra})$ of $\mathrm{ZrO}_{2}$ [36]. The negligible effect of the $\mathrm{HF}$ on the $\mathrm{ZrO}_{2}$ surface occurs due to the absence of glassy matrix, resulting in low bond strength values $[2,35,37,38]$.

4.2. Functional Monomers. Special functional monomers have been used to improve the adhesion to $\mathrm{ZrO}_{2}$. These materials present a chemical affinity for metal oxides and can be included both in resin cement and adhesives or applied directly over the ceramic surface [17]. Phosphate ester monomers, such as 10-methacryloyloxyidecyl-dihyidrogenphosphate (MDP), chemically react with $\mathrm{ZrO}_{2}$, promoting a water-resistant bond to densely sintered zirconia ceramics [20]. MDP-based resin cement is advocated as mandatory for better adhesion to $\mathrm{ZrO}_{2}$ [21, 22, 39], but some studies do not show bond advantages over conventional BIS-GMA based resin cement [17, 40]. A phosphonic acid monomer, 6-methacryloyloxyhexyl phosphonoacetate (6-MHPA), showed some form of chemical bonding to zirconia surface [9], but there is no data available regarding the effect of 6-MHPA on the resin bond strength to zirconia ceramics after severe aging conditions [9]. Another monomer commonly used in ceramic primer materials, such as MEPS (thiophosphoric methacrylate), have been tested but with no clear advantages $[17,40]$. Some nonphosphate metal primers were tested such as 6-[4-vinylbenzyln-propyl] amino-1,3,5-triazine-2,4-dithione (VBATDT), 6methacryloyloxyhexyl-2-thiouracil-5-carboxylate (MTU-6), 4-methacryloxyethyl trimellitic anhydride (4-META), and 
TABLE 3: Retrieved papers from PubMed database search are, grouped in accordance with bond strength (BS) tests, type of ceramics, surface treatment method (STM), resin cements and results for BS improvement.

\begin{tabular}{|c|c|c|c|c|c|}
\hline $\begin{array}{l}\text { Reference } \\
\text { number }\end{array}$ & BS method & $\begin{array}{c}\text { Type of } \\
\text { ceramics }\end{array}$ & STM & Resin cement & Results \\
\hline [1] & MTBS & $\begin{array}{l}\text { ZirCAD and } \\
\text { ProCAD }\end{array}$ & $\begin{array}{c}50 \mu \mathrm{m} \mathrm{Al} \mathrm{O}_{3} \mathrm{AA}+2.6 \mathrm{~nm} \\
\mathrm{Si}_{x} \mathrm{O}_{y} ; 50 \mu \mathrm{m} \mathrm{Al} \mathrm{O}_{3} \mathrm{AA}+ \\
23 \mathrm{~nm} \mathrm{Si} \mathrm{O}_{y} ; \text { CoJet }\end{array}$ & $\mathrm{C}$ and $\mathrm{B}$ cement & $\begin{array}{c}\mathrm{Si}_{x} \mathrm{O}_{y} 2.6 \mathrm{~nm}>\mathrm{CoJet}= \\
\mathrm{Si}_{x} \mathrm{O}_{y} 23 \mathrm{~nm}>\mathrm{Ctrl}\end{array}$ \\
\hline$[3]$ & Shear & $\begin{array}{l}\text { Empress II, } \\
\text { In-Ceram, } \\
\text { and } \mathrm{ZrO}_{2}\end{array}$ & $\begin{array}{c}\text { Flame treatment } \\
\left(2.5 \mathrm{~s} / \mathrm{cm}^{2}\right), \\
\left(5 \mathrm{~s} / \mathrm{cm}^{2}\right) \text {, and } \\
\left(10 \mathrm{~s} / \mathrm{cm}^{2}\right)+\text { silane. } \\
\text { Empress II- HF + silane }\end{array}$ & Variolink II & $\mathrm{HF}+$ silane yielded the best BS \\
\hline$[4,5,25]$ & MTBS & $\begin{array}{l}\text { In- } \\
\text { Ceram }\end{array}$ & $\begin{array}{l}110 \mu \mathrm{m} \mathrm{Al}_{2} \mathrm{O}_{3} \mathrm{AA}, \mathrm{CoJet}, \\
\text { and Rocatec; all silanated }\end{array}$ & Panavia F & $\begin{array}{c}\text { CoJet }=\text { Rocatec }>110 \mu \mathrm{m} \\
\mathrm{Al}_{2} \mathrm{O}_{3} \mathrm{AA}\end{array}$ \\
\hline$[8]$ & Shear & Y-TZP & $\begin{array}{l}\mathrm{HF} ; 50 \mu \mathrm{m} \mathrm{Al} \mathrm{Al}_{3} \mathrm{AA} \\
\text { diamond abrasion }\end{array}$ & Enforce & $\begin{array}{c}\text { AA }>\text { diamond abrasion }>\text { Ctrl } \\
>\text { HF }\end{array}$ \\
\hline
\end{tabular}

[9] $\quad$ TBS $\begin{gathered}\text { GN-1 ceramic } \\ \text { block }\end{gathered} \quad 70 \mu \mathrm{m} \mathrm{Al} \mathrm{O}_{3} \mathrm{AA}$

Bistite II and Tokuso Ceramic

Primer; Linkmax and GC

Ceramic Primer; Rely-X ARC

and Rely-X Ceramic Primer;

Panavia F and Clearfil

Ceramic Primer; Resicem and

Shofu Porcelain Primer or AZ

Primer

\begin{tabular}{|c|c|c|c|c|c|}
\hline$[10]$ & Microshear & Y-TZP & $53 \mu \mathrm{m} \mathrm{Al}{ }_{2} \mathrm{O}_{3} \mathrm{AA} ; \mathrm{YAG}$ laser & $\begin{array}{l}\text { Variolink II and Monobond-S; } \\
\text { NAC-100 and SCP-100 }\end{array}$ & $\begin{array}{l}\text { Variolink II: control yielded the } \\
\text { best BS } \\
\text { NAC-100: } \mathrm{AA}=\text { laser }=\text { ctrl }\end{array}$ \\
\hline$[11]$ & Shear & Y-TZP & $\begin{array}{c}\text { Silica coating; } 50 \mu \mathrm{m} \\
\mathrm{Al}_{2} \mathrm{O}_{3} \mathrm{AA} ; \mathrm{MPS} \text { and/or } \\
\text { 4-META silanes }\end{array}$ & Panavia F and SuperBonder & $\begin{array}{l}\text { SuperBonder: MPS = 4-META } \\
\text { Panavia F: MPS > 4-META }\end{array}$ \\
\hline [12] & Shear & Y-TZP & $\mathrm{TBC}+$ primers & $\begin{array}{l}\text { Rely-X ARC, epricord opaque } \\
\text { primer; AZ Primer } \\
\end{array}$ & All primers yelded BS \\
\hline$[13,26]$ & $\begin{array}{l}\text { Micro } \\
\text { shear }\end{array}$ & $\begin{array}{c}\text { Y-TZP } \\
\text { In-Ceram }\end{array}$ & $\begin{array}{c}100 \mu \mathrm{m} \mathrm{Al} \mathrm{O}_{3} \mathrm{AA} ; \text { HF glass } \\
\text { pearls }\end{array}$ & $\begin{array}{l}\text { Panavia F and Clearfil } \\
\text { Porcelain Bond }\end{array}$ & $\begin{array}{l}\text { In Ceram: } \mathrm{HF}=\mathrm{AA}>\mathrm{ctrl} \\
\text { Cercon: } \mathrm{AA}>\mathrm{Ctrl}>\mathrm{HF}\end{array}$ \\
\hline [17] & Shear & Y-TZP & $\begin{array}{l}53 \mu \mathrm{m} \mathrm{Al}_{2} \mathrm{O}_{3} \mathrm{AA} ; \mathrm{Er}: \mathrm{YAG} \\
\text { laser; primers }\end{array}$ & Calibra, Panavia F & $\mathrm{AA}+$ primers yelded high $\mathrm{BS}$ \\
\hline$[20]$ & TBS & Y-TZP & $\begin{array}{l}\text { AA; silanated; silica coated; } \\
\text { acrylized; MDP; } \\
\text { polyacid-modified } \\
\text { composite }\end{array}$ & Panavia & $\begin{array}{c}\text { MDP }>\text { acrylized }> \\
\text { polyacid-modified composite }> \\
\text { silica coated }>\text { silanated }=\text { AA }\end{array}$ \\
\hline [21] & Shear & Y-TZP & $\begin{array}{l}\mathrm{AA}+\mathrm{MDP} \text { silane; } \mathrm{AA}+ \\
\text { silane }\end{array}$ & Rely-X ARC, Panavia F & $\begin{array}{l}\text { MDP silane assured higher BS } \\
\text { for both RCs }\end{array}$ \\
\hline$[22]$ & MTBS & Y-TZP & $125 \mu \mathrm{m} \mathrm{Al}{ }_{2} \mathrm{O}_{3} \mathrm{AA}, \mathrm{TBC}$ & $\begin{array}{l}\text { Calibra; Clearfil Esthetic; } \\
\text { Rely-X Unicem }\end{array}$ & $\begin{array}{l}\text { Clearfil Esthetic yelded the best } \\
\text { BS }\end{array}$ \\
\hline$[23]$ & Shear & Y-TZP & $\begin{array}{c}125 \mu \mathrm{m} \mathrm{Al} \mathrm{O}_{3} \mathrm{AA} \text {, Clearfil } \\
\text { silanes, MDP solution, and } \\
\text { CoJet }\end{array}$ & Panavia F & $\begin{array}{c}\text { CoJet }+ \text { MDP }+ \text { silane }=\text { CoJet }+ \\
\text { silane }=\text { CoJet }>\text { Ctrl }=\mathrm{MDP}+ \\
\text { silane }=\text { silane }\end{array}$ \\
\hline$[27]$ & Shear & Y-TZP & MDP; zirconia primer & Clapearl DC & $\begin{aligned} \mathrm{MDP}= & \text { zirconia primer }=\mathrm{MDP} \\
& + \text { zirconia primer }\end{aligned}$ \\
\hline [29] & Shear & Y-TZP & $\begin{array}{l}\text { Organo } \\
\text { silane }\end{array}$ & $\begin{array}{l}\text { Rely-X ARC, experimental } \\
\text { resin }\end{array}$ & $\begin{array}{c}\text { Only isocyanatopropyltri- } \\
\text { ethoxysilane does not improve } \\
\text { BS }\end{array}$ \\
\hline$[33,74]$ & MTBS & Y-TZP & SIE and zirconia primer & Panavia F & $\begin{array}{c}\text { SIE }+ \text { primer }>\text { Ctrl. SIE }+ \\
\text { primer decreased BS with aging }\end{array}$ \\
\hline
\end{tabular}

Primer
enhanced BS except the AZ

Primer 
TABle 3: Continued.

\begin{tabular}{|c|c|c|c|c|c|}
\hline $\begin{array}{l}\text { Reference } \\
\text { number }\end{array}$ & BS method & $\begin{array}{l}\text { Type of } \\
\text { ceramics }\end{array}$ & STM & Resin cement & Results \\
\hline$[35]$ & $\begin{array}{l}\text { TBS and } \\
\text { Shear }\end{array}$ & In-Ceram & $\begin{array}{c}\text { HF; CoJet; } 25 \mu \mathrm{m} \\
\mathrm{Al}_{2} \mathrm{O}_{3} \text { AA. All silanated }\end{array}$ & $\begin{array}{l}\text { Z-100 resin applied directly to } \\
\qquad \mathrm{ZrO}_{2} \text { surface }\end{array}$ & CoJet $>\mathrm{AA}>\mathrm{HF}$ \\
\hline$[37]$ & MTBS & In-Ceram & $\begin{array}{l}\text { HF; CoJet, Silane; } \\
\mathrm{Al}_{2} \mathrm{O}_{3} \mathrm{AA} . \\
\end{array}$ & Resin block & $\begin{array}{c}\text { CoJet + silane yelded the best } \\
\text { BS }\end{array}$ \\
\hline$[38]$ & Shear & & $\begin{array}{c}\mathrm{HF} ; 25 \mu \mathrm{m} \mathrm{Al} \mathrm{Al}_{3} \mathrm{AA} ; \text { bur } \\
\text { grinding }\end{array}$ & $\begin{array}{l}\text { Panavia 21, Twinlook, and } \\
\text { Super-bond }\end{array}$ & $\begin{array}{c}\text { Grinding }+ \text { Superbond showed } \\
\text { the best BS }\end{array}$ \\
\hline [39] & MTBS & Y-TZP & $125 \mu \mathrm{m} \mathrm{Al}{ }_{2} \mathrm{O}_{3} \mathrm{AA}$, CoJet & $\begin{array}{l}\text { Calibra, Clearfil cement, and } \\
\text { Rely-X Unicem }\end{array}$ & $\begin{array}{c}\text { Phosphate } \\
\text { monomer-containing cement } \\
\text { (Clearfil) }>\text { other RCs, } \\
\text { irrespective of STMs }\end{array}$ \\
\hline$[40]$ & Shear & Y-TZP & $\begin{array}{l}50 \mu \mathrm{m} \mathrm{Al}_{2} \mathrm{O}_{3} \mathrm{AA} ; \text { Korox; } \\
\text { Rocatec; flame treatment }\end{array}$ & Panavia F & No significant differences \\
\hline $\begin{array}{l}{[41,42} \\
44,46,58]\end{array}$ & Shear & Y-TZP & $\mathrm{Al}_{2} \mathrm{O}_{3} \mathrm{AA}$ & $\begin{array}{l}\text { Alloy Primer; Super Bond } \\
\text { Monomer; Metal Primer II; } \\
\text { Panavia F, Superbonder }\end{array}$ & Primers improve BS \\
\hline$[45]$ & Shear & Y-TZP & $\begin{array}{c}\text { Zirconia primer; zirconia } \\
\text { primer heat treatment } \\
\left(45^{\circ} \mathrm{C} ; 79^{\circ} \mathrm{C} ; 100^{\circ} \mathrm{C}\right)\end{array}$ & Panavia F & $\begin{array}{l}\text { Heat treatment of zirconia } \\
\text { primer improved the early bond } \\
\text { strength }\end{array}$ \\
\hline$[52]$ & Shear & Y-TZP & $\begin{array}{l}\text { Plasma; silanized glass } \\
\text { pearls }\end{array}$ & Variolink II & Glass pearls > Plasma \\
\hline$[57]$ & TBS & Y-TZP & $\begin{array}{l}\quad 50 \mu \mathrm{m} \mathrm{Al} \mathrm{O}_{3} \mathrm{AA} ; \\
\text { air-powder-water spray }\end{array}$ & $\begin{array}{l}\text { Variolink II; Panavia F, } \\
\text { Heliobond }\end{array}$ & AA > air-powder-water spray \\
\hline [61] & Shear & Y-TZP & Rocatec & $\begin{array}{c}\text { Ketac-Cem; } \\
\text { Nexus; Superbond; } \\
\text { Panavia 21; Panavia F; Rely-X } \\
\text { Unicem } \\
\end{array}$ & Panavia 21 yelded the best BS \\
\hline$[62]$ & TBS & Y-TZP & AA; AA + HF; silica coating & Z100 & $\mathrm{AA}=\mathrm{AA}+\mathrm{HF}>$ silica coating \\
\hline$[65]$ & Shear & Y-TZP & $\begin{array}{c}70 \mu \mathrm{m} \mathrm{Al}_{2} \mathrm{O}_{3} \mathrm{AA} ; \mathrm{SiC} \\
\text { blasted }\end{array}$ & $\begin{array}{c}\text { Zinc phosphate, glass } \\
\text { ionomer, and Adhesive resin }\end{array}$ & $\begin{array}{l}\text { Adhesive resin yelded the best } \\
\text { BS }\end{array}$ \\
\hline$[66]$ & Shear & Digizon-A & $\begin{array}{l}\text { Silica coating; } 30 \mu \mathrm{m} \\
\mathrm{Al}_{2} \mathrm{O}_{3} \mathrm{AA} \text {; silanized }\end{array}$ & $\begin{array}{l}\text { Panavia EX; Panavia F 2.0; } \\
\text { Rely-X Unicem; Bifix QM; } \\
\text { Dual Cement; Duo Cement } \\
\text { Plus; Multilink Automix; } \\
\text { ParaCem; Rely-X ARC; } \\
\text { Variolink Ultra; Variolink II } \\
\end{array}$ & $\begin{array}{c}\text { Bifix QM + silica coating yelded } \\
\text { the best BS }\end{array}$ \\
\hline$[67]$ & Shear & Y-TZP & $\begin{array}{l}\text { Rocatec; silanized (Espe } \\
\text { Sil); Epricode; } \alpha \text {-alumina }\end{array}$ & Rely-X ARC & $\begin{array}{c}\text { The silane, Espe Sil yelded the } \\
\text { best BS }\end{array}$ \\
\hline$[69]$ & Shear & Y-TZP & $110 \mu \mathrm{m} \mathrm{Al}_{2} \mathrm{O}_{3} \mathrm{AA}$ & $\begin{array}{c}\text { Fuji I; Ketac Cem Easymix; } \\
\text { Fuji Plus; RelyX Luting; } \\
\text { Principle; Ionotite F; Panavia } \\
\text { F; Rely-X Unicem }\end{array}$ & $\begin{array}{c}\text { Panavia F }=\text { Principle }>\text { Fuji } \\
\text { Plus }=\text { Rely-X Unicem }>\text { Rely-X } \\
\text { Luting }=\text { Ketac Cem }>\text { FujiI }> \\
\text { Ionotite F }\end{array}$ \\
\hline [73] & Pull out & Y-TZP & $\begin{array}{c}110 \mu \mathrm{m} \mathrm{Al}_{2} \mathrm{O}_{3} \mathrm{AA} ; \text { silanized } \\
\text { glass pearls }\end{array}$ & $\begin{array}{l}\text { Zinc phosphate, Panavia 21, } \\
\text { and Variolink II }\end{array}$ & Glass pearls > AA \\
\hline$[76]$ & Shear & Y-TZP & $50 \mu \mathrm{m} \mathrm{Al}{ }_{2} \mathrm{O}_{3} \mathrm{AA}$ & $\begin{array}{c}\text { BisCem; Rely-X Unicem; } \\
\text { G-Cem; Maxcem; Clearfil SA }\end{array}$ & $\begin{array}{c}\mathrm{AA}>\mathrm{Ctrl} . \mathrm{G}-\mathrm{Cem}+\mathrm{AA} \\
\text { yielded the best BS }\end{array}$ \\
\hline$[77]$ & Shear & Y-TZP & $\begin{array}{l}\text { AA; silica coating; diamond } \\
\text { abrasion. HF; silane; } \\
\text { zirconia primer }\end{array}$ & Resin cement & $\begin{array}{c}\text { silicoated }+ \text { silanated }> \\
\text { diamond abrasion }+ \text { zirconia } \\
\text { primer }> \\
\text { AA }+ \text { silanated }>\text { zirconia } \\
\text { primer }>\text { AA }+ \text { zirconia primer }\end{array}$ \\
\hline$[60]$ & MTBS & Y-TZP & Silica coating; MDP; silane & Panavia F & $\begin{array}{c}\text { Silica coating }+ \text { silane }>\text { silica } \\
\text { coating }+\mathrm{MDP}=\mathrm{Ctrl}\end{array}$ \\
\hline
\end{tabular}


TABLE 3: Continued.

\begin{tabular}{|c|c|c|c|c|c|}
\hline $\begin{array}{l}\text { Reference } \\
\text { number }\end{array}$ & BS method & $\begin{array}{l}\text { Type of } \\
\text { ceramics }\end{array}$ & STM & Resin cement & Results \\
\hline$[71]$ & Shear & Y-TZP & $\begin{array}{l}\text { AA; YAG laser-irradiated; } \\
\text { glaze applied + HF }\end{array}$ & Clearfil Esthetic Cement & $\begin{array}{c}\text { Laser irradiated > glaze applied } \\
+\mathrm{HF}=\mathrm{AA}=\mathrm{Ctrl}\end{array}$ \\
\hline$[75]$ & Shear & Y-TZP & $\begin{array}{l}\text { CoJet; glaze + HF; glaze + } \\
\text { CoJet. All silanized }\end{array}$ & Panavia F & $\begin{array}{c}\text { Glaze }+ \text { HF }>\text { glaze }+ \text { CoJet }= \\
\text { CoJet }\end{array}$ \\
\hline$[72]$ & Shear & Y-TZP & $\begin{array}{l}\text { AA; CoJet; Er: YAG laser; } \\
\text { AA + Er: YAG laser }\end{array}$ & $\begin{array}{l}\text { Rely-X U100, Clearfil Esthetic } \\
\text { Cement, and Panavia F }\end{array}$ & $\begin{array}{c}\text { Er: YAG showed lower bond } \\
\text { strengths irrespective of } \\
\text { RC }\end{array}$ \\
\hline$[78]$ & MTBS & Y-TZP & $\begin{array}{l}\text { TBC; TBC + zirconia } \\
\text { primer }\end{array}$ & $\begin{array}{l}\text { Clearfil Esthetic Cement and } \\
\text { Panavia F }\end{array}$ & $\mathrm{TBC}+$ zirconia primer $>\mathrm{TBC}$ \\
\hline
\end{tabular}

MTBS: microtensile bond strength; TBS: tensile bond strength; SIE: selective infiltration etching; AA: air-abrasion; Ctrl: control groups with no STM; RC: resin cement; HF: hydrofluoric acid etching; TBC: tribochemical treatment.

phosphoric acid acrylate monomers, allowing additional chemical bond with zirconium/metal oxides [17, 41, 42].

The surface treatment with primers containing functional monomers such as MDP (e.g., Alloy Primer and Clearfil Ceramic Primer, Kuraray Medical Inc., Japan) or other phosphoric acid acrylate monomer (e.g., Metal/Zirconia Primer, Ivoclar-Vivadent) are often recommended to improve the bonding to $\mathrm{ZrO}_{2}$. Since results are not always significant, the combination of primers and air-abrasion methods tend to produce better bond strength, especially in longterm $[12,42-45]$. The use of new zirconia primers (a mixture of organophosphate and carboxylic acid monomers) or a phosphonic acid monomer (6-MHPA) has been tested showing good immediate results $[9,46]$.

4.3. Silane Coupling Agents. Silane coupling agents or more precisely trialkoxysilanes are hybrid inorganic-organic bifunctional molecules that are able to create a siloxane network with the hydroxyl $(\mathrm{OH})$ of the $\mathrm{Si}$ in the ceramic surface and copolymerize with the resin matrix of composites; also, silanes lower the surface tension of a substrate, wet it, and make its surface energy higher [47]. Thus, a hydrophobic matrix (resin composite) can adhere to hydrophilic surfaces, such as silica, glass, and glassceramics [29]. Different types of silanes have been studied, but none of them were able to show high effectiveness in surfaces with absent or reduced $\mathrm{Si}$ content as the surface of $\mathrm{ZrO}_{2}$ [20,41,48-52]. In addition, siloxane bonds may be sensitive to hydrolytic degradation, affecting the stability of the adhesive interface $[20,39,53]$. Organosilanes were also tested (3-methacryloyloxypropyltrimethoxysilane, 3-acryloyloxypropyltrimethoxysilane, or 3-isocyanatopropyltriethoxysilane) with better results for the two first ones [29]. The silane organofunctional groups are generally a methacrylate molecule, but acrylate groups are known to be more reactive than methacrylates [29]. The 3-isocyanatopropyltriethoxysilane is a rare silane, which has not been reported to be used as adhesion promoters in dental materials research.

\section{Mechanical Surface Treatments}

5.1. Air-Abrasion with Aluminum Oxide Particles. Air-abrasion with aluminum oxide particles $\left(\mathrm{Al}_{2} \mathrm{O}_{3}\right)$ has been studied since the nineties and its effectiveness is closely related to the sandblasted ceramic surface and the air abrasion method. Through a scanning electron microscopy (SEM) evaluation in 2003, Borges et al. [7] showed that the air-abrasion with $50 \mu \mathrm{m} \mathrm{Al} \mathrm{Al}_{2}$ during $5 \mathrm{~s}$ at 4 -bar pressure is able to create irregularities on the surface of glass ceramics; however, the same procedure did not change the surface of In-Ceram Alumina, In-Ceram Zirconia, and Procera.

During an evaluation with an optical profilometer, Della Bona et al. [36] showed an increase in the arithmetic roughness (Ra) of In-Ceram Zirconia (from $207 \mathrm{~nm}$ to $1000 \mathrm{~nm}$ ) after the use of $25 \mu \mathrm{m} \mathrm{Al} \mathrm{O}_{3}$ air-abrasion at a distance of $10 \mathrm{~mm}$ for $15 \mathrm{~s}$, at a pressure of 2.8 bars. de Oyagüe et al. [22] employed $125 \mu \mathrm{m} \mathrm{Al} \mathrm{Al}_{2}$ air-abrasion for $10 \mathrm{~s}$ at approximately 5 -bar pressure, which resulted in $45.77 \mathrm{~nm}$ for Ra, against $9.39 \mathrm{~nm}$ of the control group (notreatment), on a yttrium-stabilized tetragonal zirconia (Y-TZP) material (Cercon Zirconia, Dentsply). On the other hand, working with similar ceramics (Lava, $3 \mathrm{M}$-ESPE), Casucci et al. [54] observed just $7.11 \mathrm{~nm}$ for Ra against $6.94 \mathrm{~nm}$ on the control group (notreatment).

Since greater roughness was produced over different $\mathrm{ZrO}_{2}$ based materials, the air-abrasion method must take this fact into consideration. In-Ceram Zirconia should not be classified as pure zirconia ceramics since it is composed of $63 \%$ of alumina, $32 \%$ of zirconia, and $4 \%$ of glass matrix [36]. In addition, alumina is less ductile than zirconia, with larger grains and higher surface hardness, which makes airabrasion more effective [55]. Contradictory results from the studies of de Oyagüe et al. [22] and Casucci et al. [54] may be possibly related to the different ceramic brands they used.

When it comes to abrasion with $\mathrm{Al}_{2} \mathrm{O}_{3}$, a wide range of particle size, pressure, distance from ceramic surface, working time, and impact angle have been studied. These differences can help explain contradictory results. Although studies consider the previous factors important [56], the type of the $\mathrm{ZrO}_{2}$ ceramics may be mandatory. On a yttriumstabilized tetragonal zirconia (Y-TZP) material, the use of greater particle size (from $50 \mu \mathrm{m}$ to $150 \mu \mathrm{m}$ ) results in a rougher surface but no significant alteration in bond strength [41]. Evaluating a Y-TZP, Cavalcanti et al. [17] showed an increase in bond strength after air-abrasion with $50 \mu \mathrm{m} \mathrm{Al}_{2} \mathrm{O}_{3}$ for 15 seconds at 2.5 bars. With similar ceramics de Oyagüe 
et al. [22] showed that air-abrasion did not produce higher bond strength, even though the substrate surface became rougher than the control group (as shown in the previous paragraph). Several studies have shown low bond strength values with air-abrasion $[20,39,54,57]$ or even spontaneous debonding after artificial aging (150 days of water storage and repeated thermocycling) on the association of airborne particle abrasion, silane application, and Bis-GMA resin cement [20]. According to Kern et al. [58] air-abrasion without primers can result in higher initial bond strength to zirconia ceramics that will be reduced to zero in long-term evaluation, independent of air-abrasion application pressure.

5.2. Si Deposition Methods. Si deposition methods started in 1984 with the silicoater technology [13], and in 1989 the Rocatec system, a laboratory device, was developed and later the CoJet system, a chairside device was introduced into the market [59]. These systems are based on the use of $110 \mu \mathrm{m}$ (Rocatec) or $30 \mu \mathrm{m}$ (CoJet) Si-coated alumina particles that are blasted onto the ceramic surface. Sandblasted ceramics acquires a reactive $\mathrm{Si}$-rich outer surface prone to silanization and the following $\mathrm{AC}$ with suitable resin composites. Its use requires silane application before cementation $[28,60]$. The tribochemical Si-coating on ceramic surfaces increases the bond strength of resin cement to glass-infiltrated $\mathrm{ZrO}_{2}$ [5, 24, 59] or Y-TZP [61-64]. Usually, 2.5-2.8-bar air-abrasion pressures are used $[4,23]$; however, higher pressure results in higher bond strength with CoJet [55]. In spite of that, some studies still show similar shear bond strength with and without Si-coating by air-abrasion methods [65].

Si deposition by air-abrasion might produce a more silane reactive surface [66], but it also tends to produce a surface with lower roughness and consequently lower possibility of mechanical interlocking with resin cement [22, 29]. Some authors do not show lower roughness [67], but considering this might be a true observation; the enabled chemical interaction to resin cement or coupling agents would justify its use [68].

\section{Alternative Treatments}

Different alternative methods to treat $\mathrm{ZrO}_{2}$ surfaces have been proposed and evaluated in order to produce a reliable adhesion, especially in long term. A large range of mechanical, chemical, or both approaches have been tried to modify the $\mathrm{ZrO}_{2}$ surface to increase the surface bond area, surface energy, or wettability [69].

Plasma spraying (hexamethyldisiloxane) using a reactor (Plasma Electronic, Germany), proposed in a previous study [52], increased the bond strength of resin cement to $\mathrm{ZrO}_{2}$. The authors related that plasma is a partially ionized gas containing ions, electrons, atoms, and neutral species. However, the mechanism of surface modification and rise of the bond strength remain unclear, and the authors suggested that the improvement in bond strength might be explained by covalent bonds [52].

Some studies have suggested the use of erbium-doped yttrium aluminum garnet (Er:YAG) or $\mathrm{CO}_{2}$ laser to enhance the bond strength to resin cement $[17,30,70,71]$; therefore, the effect of laser on the $\mathrm{ZrO}_{2}$ could be tested with the same aim. Laser application removed particles by microexplosions and by vaporization, a process called ablation. However, bond strength results indicated that the effect of laser irradiation is contradictory. While some studies concluded that lasers are not effective to improve the bond strength between $\mathrm{ZrO}_{2}$ and resin cement $[17,30,72]$, recent research shows the improvement of adhesion after $\mathrm{CO}_{2}$ laser application in comparison to conventional STM and indicates this technique as an alternative method for bonding to $\mathrm{ZrO}_{2}$ surfaces.

The applications of micropearls of low fusing porcelain or vapor deposition of silicon tetrachloride $\left(\mathrm{SiCl}_{4}\right)$ are other types of silicatization methods that have been used, showing improved bond strength $[52,73]$.

However, the most innovative STM for $\mathrm{ZrO}_{2}$ was introduced by Aboushelib et al. in 2006 and tested with respect to microtensile bond strength in 2007 [31]. This method was named selective infiltration etching (SIE) and uses principles of heat-induced maturation and grain boundary diffusion to transform the relatively smooth nonretentive surface of Y-TZP into a highly retentive surface. A low temperature molting glass is applied on selected $\mathrm{ZrO}_{2}$ surfaces and submitted to a heat-induced infiltration process, determining zirconia crystal rearrangements. After that, the glass is removed with a $5 \%$ hydrofluoric acid solution bath, leaving intergrain nanoporosities where low-viscosity resin materials may flow and interlock after polymerization [31]. This method was tested in association with MDP-based resin cement, providing high and durable bond strength [31, 32], and with previous application of zirconia primers, providing increased initial bond strength [74] but not a stable bond with artificial aging [33].

Recent studies has shown promising results on bond strengths of $\mathrm{Y}-\mathrm{TZP} /$ resin cement after glazed ceramic surface is subjected to air-particle abrasion with aluminum oxide and silanization [1] or etching with hydrofluoric acid [75], but a stable bond promoted by these methods is questionable and needs more studies.

Irrespective of the possibility of producing a rough surface with air-abrasion or SIE, these methods still do not completely assure better or durable bond strength, as it could be seen. To overcome this issue, it is clear that micromechanical plus chemical adhesion strategies should be used.

\section{Discussion}

Several surface treatment methods have been proposed to overcome intrinsic acid resistance of $\mathrm{ZrO}_{2}$; however, these methods have presented controversial results about their effectiveness on bond strength improvement. Nonetheless it seems important to select multifunctional methods, which mix the ability to create a rough surface for micromechanical interlocking and increase the surface area to establish chemical bond with reactive substances. When testing self-adhesive luting resin cement containing a functional phosphate monomer, Yang et al. [42] showed reliable bond strength after air-abrasion at 2.5 bars or the combination of low pressure air-abrasion and priming with MDP-containing primers. Therefore, air-abrasion seems to be important even 
TABLE 4: Guide to suggested STM for $\mathrm{ZrO}_{2}$ ceramics.

\begin{tabular}{|c|c|c|c|c|}
\hline Ceramics type & Commercial brands & STM & Primers/silane & Resin cement (RC) \\
\hline \multirow[t]{2}{*}{$\mathrm{Y}-\mathrm{TZP} \mathrm{ZrO}_{2}$} & \multirow[t]{2}{*}{$\begin{array}{l}\text { Lava, Cercon, Emax } \\
\text { ZIR-CAD, Procera } \\
\text { Zirconia }\end{array}$} & \multirow{2}{*}{$\begin{array}{l}50-150 \mu \mathrm{m} \\
\mathrm{Al}_{2} \mathrm{O}_{3} \text { air-abrasion, with } 2.5 \\
\text { bars, } 10 \mathrm{~mm} \text { distance, for } 15 \\
\text { seconds }\end{array}$} & Dhoonberemonomor & $\begin{array}{l}\text { Phosphate monomer con- } \\
\text { taining RC (Rely-X U200, } \\
\text { Panavia F, and Panavia 2.1) }\end{array}$ \\
\hline & & & $\begin{array}{c}\text { containing solutions: Alloy } \\
\text { Primer, Clearfil Ceramic } \\
\text { Primer, or Kuraray's } \\
\text { Clearfil Repair Kit }\end{array}$ & $\begin{array}{l}\text { Dual or chemical cured RC } \\
\text { (check compatibility with } \\
\text { previous applied solutions) }\end{array}$ \\
\hline \multirow[t]{2}{*}{ Glass infiltrated $\mathrm{ZrO}_{2}$} & \multirow[t]{2}{*}{ In-Ceram Zirconia } & $\begin{array}{c}25 \mu \mathrm{m} \mathrm{Al}_{2} \mathrm{O}_{3} \text { air-abrasion } \\
\text { with } 2.8 \text { bars, } 10 \mathrm{~mm} \\
\text { distance, for } 15 \mathrm{~s} .\end{array}$ & 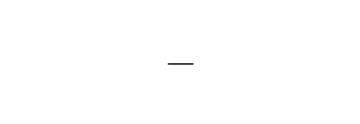 & $\begin{array}{l}\text { Phosphate monomer con- } \\
\text { taining RC (Rely-X U200, } \\
\text { Panavia F, and Panavia 2.1) }\end{array}$ \\
\hline & & $\begin{array}{c}\text { Air-abrasion with } \\
\text { Si-coating } \mathrm{Al}_{2} \mathrm{O}_{3} \text { particles } \\
\text { (CoJet or Rocatec system), } \\
\text { at } 4.5 \text { bars, } 10 \mathrm{~mm} \text { distance, } \\
\text { for } 10 \mathrm{~s} .\end{array}$ & $\begin{array}{c}\text { Phosphate monomer } \\
\text { containing solutions: Alloy } \\
\text { Primer, Clearfil Ceramic } \\
\text { Primer, or Kuraray's } \\
\text { Clearfil Repair Kit }\end{array}$ & $\begin{array}{l}\text { Dual or chemical cured RC } \\
\text { (check compatibility with } \\
\text { previous applied solutions) }\end{array}$ \\
\hline
\end{tabular}

when working with phosphate monomer resin cement [44] or with conventional self-adhesive resin cement [76]. If conventional resin cement is to be used, primer application seems mandatory for durable adhesion [58].

STM development shows the need for producing high roughness and chemical interaction on $\mathrm{ZrO}_{2}$ ceramic surfaces. According to the analysis of the selected papers it could be seen that the use of $\mathrm{Al}_{2} \mathrm{O}_{3}$ air-abrasion followed by application of phosphate monomers-based primers or resin cement tends to produce more reliable results $[13,39,42,57$, 61 . However, SIE also produces a rough surface, with optimal surface energy and interaction with resin cement [31], with the advantage of being user-controlled and depth-limited.

Similar to phosphate monomer solutions/cements, the use of metal primers can also establish chemical bond with zirconia [17]. Magne et al. [46] showed promising results with a special designed zirconia primer solution. An important point is that a functional monomer is not necessary in the resin luting agent if it is contained in the primer [21]. Optimal results were found with MDP-based resin cement [32]. However, when working with Bis-GMA based resin cement, Si-coating plus silane application produces good results [61, 77]. In addition, according to Kern et al. [58] the use of primers for conventional resin cement will result in long-term bond strength after air-abrasion. Thereby, adhesion to $\mathrm{ZrO}_{2}$ seems mainly promoted by chemical bonds, either through hydrogen bonds between the polar functional groups of the polymers or monomers in the cement and the polar hydroxyl groups available on $\mathrm{ZrO}_{2}$ surface or between siloxane bonds on $\mathrm{ZrO}_{2} \mathrm{Si}$-coated surfaces. Therefore the main function of air-abrasion is to clean and increase the surface area $[12,42$, $58]$, creating the conditions to establish the chemical bonds.

Even with a significant increase of $\mathrm{Si}$ ratio $(76 \%)$ at the surface after Si-coating via air-abrasion (CoJet system) [36], which may enhance bonding to resin by silane coupling, $\mathrm{Si}$ coated surfaces of In-Ceram Zirconia remain almost similar to their original state since an increase from $1.25 \%$ to only $2.21 \%$ of $\mathrm{Si}$ could be noted on the $\mathrm{ZrO}_{2}$ surface [36]. YTZP Si-coated surfaces showed $4.2 \%$ of $\mathrm{Si}$ (by weight) and
11.2\% atomic concentration [29]. The presence of $\mathrm{Si}$ is a prerequisite for durable siloxane bonding, and so on, some authors considered the above mentioned $\mathrm{Si}$ concentrations at zirconia surfaces too silicon-poor for durable bonding [29]. However, Inokoshi et al. [78] showed that the combination of Si-coating via air-abrasion (CoJet system) and zirconia primers presents durable bond to $\mathrm{ZrO}_{2}$.

Glass pearls or silicon tetrachloride $\left(\mathrm{SiCl}_{4}\right)$ vapor deposition is new methods that deserve more research considering the ability to increase Si-concentration $[1,73]$. This information reinforces the importance of the chemical bonds for a durable and reliable adhesion between the substrates (resin cement and $\mathrm{ZrO}_{2}$ ).

On a Si-coated surface, silane bonding could be complemented by the use of monomers with metal affinity, such as MDP, present in metal and ceramic primers. However, previous silane application would prevent the contact between these functional monomers and the ceramic surface avoiding the hydrogen bond formation, except when the silane solution is mixed with MDP (e.g., Kuraray's Clearfil Repair Kit) [29]. With MDP-resin cement, Atsu et al. [23] proved this assumption, showing that tribochemical Sicoating (CoJet System) and the application of an MDPcontaining bonding/silane coupling agent mixture increased the shear bond strength. In addition, according to Tanaka et al. [67] stable shear bond strength can be achieved on Sicoated Y-TZP with the cooperative interaction of hydrogen bond formed between phosphate monomer and $\mathrm{ZrO}_{2}$ and silane coupling to $\mathrm{SiO}_{2}$ incorporated to ceramic surface. In this case, silane application will increase ceramic surface wettability for the resin cement rather than establishing siloxane bonds.

Collected observations from all analyzed studies are sometimes conflicting, and this may be specially caused by different testing methods. Table 3 summarized the testing methods, and although most of them employed microtensile tests (the most suitable one for bond strength testing [79]), results are still controversial; thus, more work is necessary to draw definitive conclusions. Based on state-of-the-art 
concepts, Table 4 contains suggested STM protocols for the $\mathrm{AC}$ of $\mathrm{ZrO}_{2}$ ceramic restorations.

As a final consideration, it is always important to emphasize that the composition of the $\mathrm{ZrO}_{2}$ to be used is critical when choosing the best surface treatment. In addition, distance, pressure, working time, and particle's composition of air abrasion must be carefully observed. The type of the resin cement may be defined by the type of STM, depending on the compatibility of the selected functional monomer or on the creation of a siloxane bond after considering the presence and quantity of $\mathrm{Si}$ at $\mathrm{ZrO}_{2}$ surface.

\section{Conclusions}

According the reviewed literature it was possible to conclude that

(1) STMs must be correlated to the type of $\mathrm{ZrO}_{2}$ and the selected resin cement;

(2) airborne-particle abrasion combined with a resin composite containing phosphate monomers or tribochemical Si-coating plus silane (with functional monomers) coating combined with conventional BisGMA resin cement could be considered the best STMs;

(3) primer development seems to be an effective method to improve bond strength to $\mathrm{ZrO}_{2}$;

(4) alternative STMs (selective infiltration etching or Sicoating or plasma treatment) have presented considerable surface alterations and have shown promising results; however, further studies are necessary.

\section{Disclosure}

The authors disclose no commercial interest in products or companies mentioned in the paper.

\section{References}

[1] J. R. Piascik, E. J. Swift, J. Y. Thompson, S. Grego, and B. R. Stoner, "Surface modification for enhanced silanation of zirconia ceramics," Dental Materials, vol. 25, no. 9, pp. 1116-1121, 2009.

[2] M. B. Blatz, A. Sadan, and M. Kern, "Resin-ceramic bonding: a review of the literature," Journal of Prosthetic Dentistry, vol. 89, no. 3, pp. 268-274, 2003.

[3] R. Janda, J. F. Roulet, M. Wulf, and H. J. Tiller, "A new adhesive technology for all-ceramics," Dental Materials, vol. 19, no. 6, pp. 567-573, 2003.

[4] R. Amaral, M. Özcan, L. F. Valandro, I. Balducci, and M. A. Bottino, "Effect of conditioning methods on the microtensile bond strength of phosphate monomer-based cement on zirconia ceramic in dry and aged conditions," Journal of Biomedical Materials Research B, vol. 85, no. 1, pp. 1-9, 2008.

[5] M. A. Bottino, L. F. Valandro, R. Scotti, and L. Buso, "Effect of surface treatments on the resin bond to zirconium-based ceramic," International Journal of Prosthodontics, vol. 18, no. 1, pp. 60-65, 2005.
[6] A. Della Bona and K. J. Anusavice, "Microstructure, composition, and etching topography of dental ceramics," International Journal of Prosthodontics, vol. 15, no. 2, pp. 159-167, 2002.

[7] G. A. Borges, A. M. Sophr, M. F. de Goes, L. C. Sobrinho, and D. C. N. Chan, "Effect of etching and airborne particle abrasion on the microstructure of different dental ceramics," Journal of Prosthetic Dentistry, vol. 89, no. 5, pp. 479-488, 2003.

[8] W. Awliya, A. Odén, P. Yaman, J. B. Dennison, and M. E. Razzoog, "Shear bond strength of a resin cement to densely sintered high-purity alumina with various surface conditions," Acta Odontologica Scandinavica, vol. 56, no. 1, pp. 9-13, 1998.

[9] S. Kitayama, T. Nikaido, R. Takahashi et al., "Effect of primer treatment on bonding of resin cements to zirconia ceramic," Dental Materials, vol. 26, no. 5, pp. 426-432, 2010.

[10] R. M. Foxton, A. N. Cavalcanti, M. Nakajima et al., "Durability of resin cement bond to aluminium oxide and zirconia ceramics after air abrasion and laser treatment," Journal of Prosthodontics, vol. 20, no. 2, pp. 84-92, 2011.

[11] M. Özcan, C. Cura, and L. F. Valandro, "Early bond strength of two resin cements to Y-TZP ceramic using MPS or MPS/4META silanes," Odontology, vol. 99, no. 1, pp. 62-67, 2011.

[12] K. Takeuchi, A. Fujishima, A. Manabe et al., "Combination treatment of tribochemical treatment and phosphoric acid ester monomer of zirconia ceramics enhances the bonding durability of resin-based luting cements," Dental Materials Journal, vol. 29, no. 3, pp. 316-323, 2010.

[13] S. M. P. Torres, G. A. Borges, A. M. Spohr, A. A. D. B. Cury, S. Yadav, and J. A. Platt, "The effect of surface treatments on the micro-shear bond strength of a resin luting agent and four allceramic systems," Operative Dentistry, vol. 34, no. 4, pp. 399407, 2009.

[14] F. J. T. Burke, G. J. P. Fleming, D. Nathanson, and P. M. Marquis, "Are adhesive technologies needed to support ceramics? An assessment of the current evidence," Journal of Adhesive Dentistry, vol. 4, no. 1, pp. 7-22, 2002.

[15] C. J. Soares, P. V. Soares, J. C. Pereira, and R. B. Fonseca, "Surface treatment protocols in the cementation process of ceramic and laboratory-processed composite restorations: a literature review," Journal of Esthetic and Restorative Dentistry, vol. 17, no. 4, pp. 224-235, 2005.

[16] C. J. Soares, L. R. M. Martins, R. B. Fonseca, L. Correr-Sobrinho, and A. J. Fernandes Neto, "Influence of cavity preparation design on fracture resistance of posterior Leucite-reinforced ceramic restorations," Journal of Prosthetic Dentistry, vol. 95, no. 6, pp. 421-429, 2006.

[17] A. N. Cavalcanti, R. M. Foxton, T. F. Watson, M. T. Oliveira, M. Giannini, and G. M. Marchi, "Bond strength of resin cements to a zirconia ceramic with different surface treatments," Operative Dentistry, vol. 34, no. 3, pp. 280-287, 2009.

[18] S. M. Wegner and M. Kern, "Long-term resin bond strength to zirconia ceramic," Journal of Adhesive Dentistry, vol. 2, no. 2, pp. $139-147,2000$

[19] S. M. Wegner and M. Kern, "Long-term resin bond strength to zirconia ceramic," Journal of Esthetic and Restorative Dentistry, vol. 16, no. 5, pp. 327-328, 2004.

[20] M. Kern and S. M. Wegner, "Bonding to zirconia ceramic: adhesion methods and their durability," Dental Materials, vol. 14, no. 1, pp. 64-71, 1998.

[21] M. B. Blatz, A. Sadan, J. Martin, and B. Lang, "In vitro evaluation of shear bond strengths of resin to densely-sintered high-purity zirconium-oxide ceramic after long-term storage and thermal 
cycling," Journal of Prosthetic Dentistry, vol. 91, no. 4, pp. 356$362,2004$.

[22] R. C. de Oyagüe, F. Monticelli, M. Toledano, E. Osorio, M. Ferrari, and R. Osorio, "Influence of surface treatments and resin cement selection on bonding to densely-sintered zirconiumoxide ceramic," Dental Materials, vol. 25, no. 2, pp. 172-179, 2009.

[23] S. S. Atsu, M. A. Kilicarslan, H. C. Kucukesmen, and P. S. Aka, "Effect of zirconium-oxide ceramic surface treatments on the bond strength to adhesive resin," Journal of Prosthetic Dentistry, vol. 95, no. 6, pp. 430-436, 2006.

[24] L. F. Valandro, M. Özcan, M. C. Bottino et al., "Bond strength of a resin cement to high-alumina and zirconia-reinforced ceramics: the effect of surface conditioning," Journal of Adhesive Dentistry, vol. 8, no. 3, pp. 175-181, 2006.

[25] R. Amaral, M. Özcan, M. A. Bottino, and L. F. Valandro, "Microtensile bond strength of a resin cement to glass infiltrated zirconia-reinforced ceramic: the effect of surface conditioning," Dental Materials, vol. 22, no. 3, pp. 283-290, 2006.

[26] M. Özcan and P. K. Vallittu, "Effect of surface conditioning methods on the bond strength of luting cement to ceramics," Dental Materials, vol. 19, no. 8, pp. 725-731, 2003.

[27] K. Yoshida, Y. Tsuo, and M. Atsuta, "Bonding of dual-cured resin cement to zirconia ceramic using phosphate acid ester monomer and zirconate coupler," Journal of Biomedical Materials Research B, vol. 77, no. 1, pp. 28-33, 2006.

[28] J. P. Matinlinna, L. V. J. Lassila, and P. K. Vallittu, "Pilot evaluation of resin composite cement adhesion to zirconia using a novel silane system," Acta Odontologica Scandinavica, vol. 65, no. 1, pp. 44-51, 2007.

[29] J. P. Matinlinna, T. Heikkinen, M. Özcan, L. V. J. Lassila, and P. K. Vallittu, "Evaluation of resin adhesion to zirconia ceramic using some organosilanes," Dental Materials, vol. 22, no. 9, pp. 824-831, 2006.

[30] B. Ersu, B. Yuzugullu, A. Ruya Yazici, and S. Canay, "Surface roughness and bond strengths of glass-infiltrated aluminaceramics prepared using various surface treatments," Journal of Dentistry, vol. 37, no. 11, pp. 848-856, 2009.

[31] M. N. Aboushelib, C. J. Kleverlaan, and A. J. Feilzer, "Selective infiltration-etching technique for a strong and durable bond of resin cements to zirconia-based materials," Journal of Prosthetic Dentistry, vol. 98, no. 5, pp. 379-388, 2007.

[32] M. N. Aboushelib, A. J. Feilzer, and C. J. Kleverlaan, "Bonding to zirconia using a new surface treatment," Journal of Prosthodontics, vol. 19, no. 5, pp. 340-346, 2010.

[33] M. N. Aboushelib, H. Mirmohamadi, J. P. Matinlinna, E. Kukk, H. F. Ounsi, and Z. Salameh, "Innovations in bonding to zirconia-based materials. Part II: focusing on chemical interactions," Dental Materials, vol. 25, no. 8, pp. 989-993, 2009.

[34] J. W. McLean and T. H. Hughes, "The reinforcement of dental porcelain with ceramic oxides," British Dental Journal, vol. 119, no. 6, pp. 251-267, 1965.

[35] A. Della Bona, M. Borba, P. Benetti, and D. Cecchetti, "Effect of surface treatments on the bond strength of a zirconia-reinforced ceramic to composite resin," Brazilian Oral Research, vol. 21, no. 1, pp. 10-15, 2007.

[36] A. Della Bona, T. A. Donassollo, F. F. Demarco, A. A. Barrett, and J. J. Mecholsky Jr., "Characterization and surface treatment effects on topography of a glass-infiltrated alumina/zirconiareinforced ceramic," Dental Materials, vol. 23, no. 6, pp. 769775, 2007.
[37] T. A. Donassollo, F. F. Demarco, and A. Della Bona, "Resin bond strength to a zirconia-reinforced ceramic after different surface treatments," General Dentistry, vol. 57, no. 4, pp. 374-379, 2009.

[38] P. Dérand and T. Dérand, "Bond strength of luting cements to zirconium oxide ceramics," International Journal of Prosthodontics, vol. 13, no. 2, pp. 131-135, 2000.

[39] R. C. Oyagüe, F. Monticelli, M. Toledano, E. Osorio, M. Ferrari, and R. Osorio, "Effect of water aging on microtensile bond strength of dual-cured resin cements to pre-treated sintered zirconium-oxide ceramics," Dental Materials, vol. 25, no. 3, pp. 392-399, 2009.

[40] M. Özcan, H. Nijhuis, and L. F. Valandro, "Effect of various surface conditioning methods on the adhesion of dual-cure resin cement with MDP functional monomer to zirconia after thermal aging," Dental Materials Journal, vol. 27, no. 1, pp. 99104, 2008.

[41] Y. Tsuo, K. Yoshida, and M. Atsuta, "Effects of alumina-blasting and adhesive primers on bonding between resin luting agent and zirconia ceramics," Dental Materials Journal, vol. 25, no. 4, pp. 669-674, 2006.

[42] B. Yang, A. Barloi, and M. Kern, "Influence of air-abrasion on zirconia ceramic bonding using an adhesive composite resin," Dental Materials, vol. 26, no. 1, pp. 44-50, 2010.

[43] F. Lehmann and M. Kern, "Durability of resin bonding to zirconia ceramic using different primers," The Journal of Adhesive Dentistry, vol. 11, no. 6, pp. 479-483, 2009.

[44] J. Y. Yun, S. R. Ha, J. B. Lee, and S. H. Kim, "Effect of sandblasting and various metal primers on the shear bond strength of resin cement to Y-TZP ceramic," Dental Materials, vol. 26, no. 7, pp. 650-658, 2010.

[45] L. Silva, A. Costa, J. Queiroz, M. Bottino, and L. Valandro, "Ceramic primer heat-treatment effect on resin cement/Y-TZP bond strength," Operative Dentistry, vol. 37, no. 6, pp. 634-640, 2012.

[46] P. Magne, M. P. G. Paranhos, and L. H. Burnett Jr., "New zirconia primer improves bond strength of resin-based cements," Dental Materials, vol. 26, no. 4, pp. 345-352, 2010.

[47] J. P. Matinlinna, L. V. J. Lassila, M. Özcan, A. Yli-Urpo, and P. K. Vallittu, "An introduction to silanes and their clinical applications in dentistry," International Journal of Prosthodontics, vol. 17, no. 2, pp. 155-164, 2004.

[48] N. Barghi, "To silanate or not to silanate: making a clinical decision," Compendium of Continuing Education in Dentistry, vol. 21, no. 8, pp. 659-666, 2000.

[49] R. Frankenberger, N. Krämer, and J. Sindel, "Repair strength of etched vs silica-coated metal-ceramic and all-ceramic restorations," Operative Dentistry, vol. 25, no. 3, pp. 209-215, 2000.

[50] H. R. Horn, "Porcelain laminate veneers bonded to etched enamel," Dental Clinics of North America, vol. 27, no. 4, pp. 671684, 1983.

[51] K. J. M. Soderholm and S. W. Shang, "Molecular orientation of siliane at the surface of colloidal silica," Journal of Dental Research, vol. 72, no. 6, pp. 1050-1054, 1993.

[52] T. Derand, M. Molin, and K. Kvam, "Bond strength of composite luting cement to zirconia ceramic surfaces," Dental Materials, vol. 21, no. 12, pp. 1158-1162, 2005.

[53] L. F. Valandro, M. Özcan, R. Amaral, F. P. P. Leite, and M. A. Bottino, "Microtensile bond strength of a resin cement to silicacoated and silanized in-ceram zirconia before and after aging," International Journal of Prosthodontics, vol. 20, no. 1, pp. 70-72, 2007. 
[54] A. Casucci, E. Osorio, R. Osorio et al., "Influence of different surface treatments on surface zirconia frameworks," Journal of Dentistry, vol. 37, no. 11, pp. 891-897, 2009.

[55] T. T. Heikkinen, L. V. J. Lassila, J. P. Matinlinna, and P. K. Vallittu, "Effect of operating air pressure on tribochemical silica-coating," Acta Odontologica Scandinavica, vol. 65, no. 4, pp. 241-248, 2007.

[56] M. Kern and V. P. Thompson, "Sandblasting and silica-coating of dental alloys: volume loss, morphology and changes in the surface composition," Dental Materials, vol. 9, no. 3, pp. 155-161, 1993.

[57] M. Wolfart, F. Lehmann, S. Wolfart, and M. Kern, "Durability of the resin bond strength to zirconia ceramic after using different surface conditioning methods," Dental Materials, vol. 23, no. 1, pp. 45-50, 2007.

[58] M. Kern, A. Barloi, and B. Yang, "Surface conditioning influences zirconia ceramic bonding," Journal of Dental Research, vol. 88, no. 9, pp. 817-822, 2009.

[59] M. Kern and V. P. Thompson, "Bonding to glass infiltrated alumina ceramic: adhesive methods and their durability," The Journal of Prosthetic Dentistry, vol. 73, no. 3, pp. 240-249, 1995.

[60] C. Chen, C. J. Kleverlaan, and A. J. Feilzer, "Effect of an experimental zirconia-silica coating technique on micro tensile bond strength of zirconia in different priming conditions," Dental Materials, vol. 28, no. 8, pp. e127-e134, 2012.

[61] H. Lüthy, O. Loeffel, and C. H. F. Hammerle, "Effect of thermocycling on bond strength of luting cements to zirconia ceramic," Dental Materials, vol. 22, no. 2, pp. 195-200, 2006.

[62] B. K. Kim, H. E. K. Bae, J. S. Shim, and K. W. Lee, "The influence of ceramic surface treatments on the tensile bond strength of composite resin to all-ceramic coping materials," Journal of Prosthetic Dentistry, vol. 94, no. 4, pp. 357-362, 2005.

[63] D. Re, D. Augusti, I. Sailer, D. Spreafico, and A. Cerutti, “The effect of surface treatment on the adhesion of resin cements to Y-TZP," The European Journal of Esthetic Dentistry, vol. 3, no. 2, pp. 186-196, 2008.

[64] A. Piwowarczyk, H. C. Lauer, and J. A. Sorensen, "The shear bond strength between luting cements and zirconia ceramics after two pre-treatments," Operative Dentistry, vol. 30, no. 3, pp. 382-388, 2005.

[65] M. Uo, G. Sjögren, A. Sundh, M. Goto, F. Watari, and M. Bergman, "Effect of surface condition of dental zirconia ceramic (Denzir) on bonding," Dental Materials Journal, vol. 25, no. 3, pp. 626-631, 2006.

[66] F. P. Nothdurft, P. J. Motter, and P. R. Pospiech, "Effect of surface treatment on the initial bond strength of different luting cements to zirconium oxide ceramic," Clinical Oral Investigations, vol. 13, no. 2, pp. 229-235, 2009.

[67] R. Tanaka, A. Fujishima, Y. Shibata, A. Manabe, and T. Miyazaki, "Cooperation of phosphate monomer and silica modification on zirconia," Journal of Dental Research, vol. 87, no. 7, pp. 666-670, 2008.

[68] M. B. Blatz, G. Chiche, S. Holst, and A. Sadan, "Influence of surface treatment and simulated aging on bond strengths of luting agents to zirconia," Quintessence International, vol. 38, no. 9, pp. 745-753, 2007.

[69] M. J. Kim, Y. K. Kim, K. H. Kim, and T. Y. Kwon, "Shear bond strengths of various luting cements to zirconia ceramic: surface chemical aspects," Journal of Dentistry, vol. 39, no. 11, pp. 795803, 2011.
[70] Ç. Ural, T. Külünk, Ş. Külünk, M. Kurt, and S. Baba, "Determination of resin bond strength to zirconia ceramic surface using different primers," Acta Odontologica Scandinavica, vol. 69, no. 1, pp. 48-53, 2011.

[71] A. Usumez, N. Hamdemirci, B. Y. Koroglu, I. Simsek, O. Parlar, and T. Sari, "Bond strength of resin cement to zirconia ceramic with different surface treatments," Lasers in Medical Science, vol. 28, no. 1, pp. 259-266, 2013.

[72] M. G. Subasi and O. Inan, "Influence of surface treatments and resin cement selection on bonding to zirconia," Lasers in Medical Science, 2012.

[73] T. Derand, M. Molin, E. Kleven, P. Haag, and S. Karlsson, "Bond strength of luting materials to ceramic crowns after different surface treatments," The European Journal of Prosthodontics and Restorative Dentistry, vol. 16, no. 1, pp. 35-38, 2008.

[74] M. N. Aboushelib, J. P. Matinlinna, Z. Salameh, and H. Ounsi, "Innovations in bonding to zirconia-based materials: part I," Dental Materials, vol. 24, no. 9, pp. 1268-1272, 2008.

[75] A. Vanderlei, M. Bottino, and L. Valandro, "Evaluation of resin bond strength to yttria-stabilized tetragonal zirconia and framework marginal fit: comparison of different surface conditionings," Operative Dentistry, 2013.

[76] M. B. Blatz, J. H. Phark, F. Ozer et al., "In vitro comparative bond strength of contemporary self-adhesive resin cements to zirconium oxide ceramic with and without air-particle abrasion," Clinical Oral Investigations, vol. 14, no. 2, pp. 187-192, 2010.

[77] D. M. Qeblawi, C. A. Muñoz, J. D. Brewer, and E. A. Monaco Jr., "The effect of zirconia surface treatment on flexural strength and shear bond strength to a resin cement," Journal of Prosthetic Dentistry, vol. 103, no. 4, pp. 210-220, 2010.

[78] M. Inokoshi, A. Kameyama, J. de Munck, S. Minakuchi, and B. van Meerbeek, "Durable bonding to mechanically and/or chemically pre-treated dental zirconia," Journal of Dentistry, vol. 41, no. 2, pp. 170-179, 2013.

[79] H. Sano, "Microtensile testing, nanoleakage, and biodegradation of resin-dentin bonds," Journal of Dental Research, vol. 85, no. 1, pp. 11-14, 2006. 

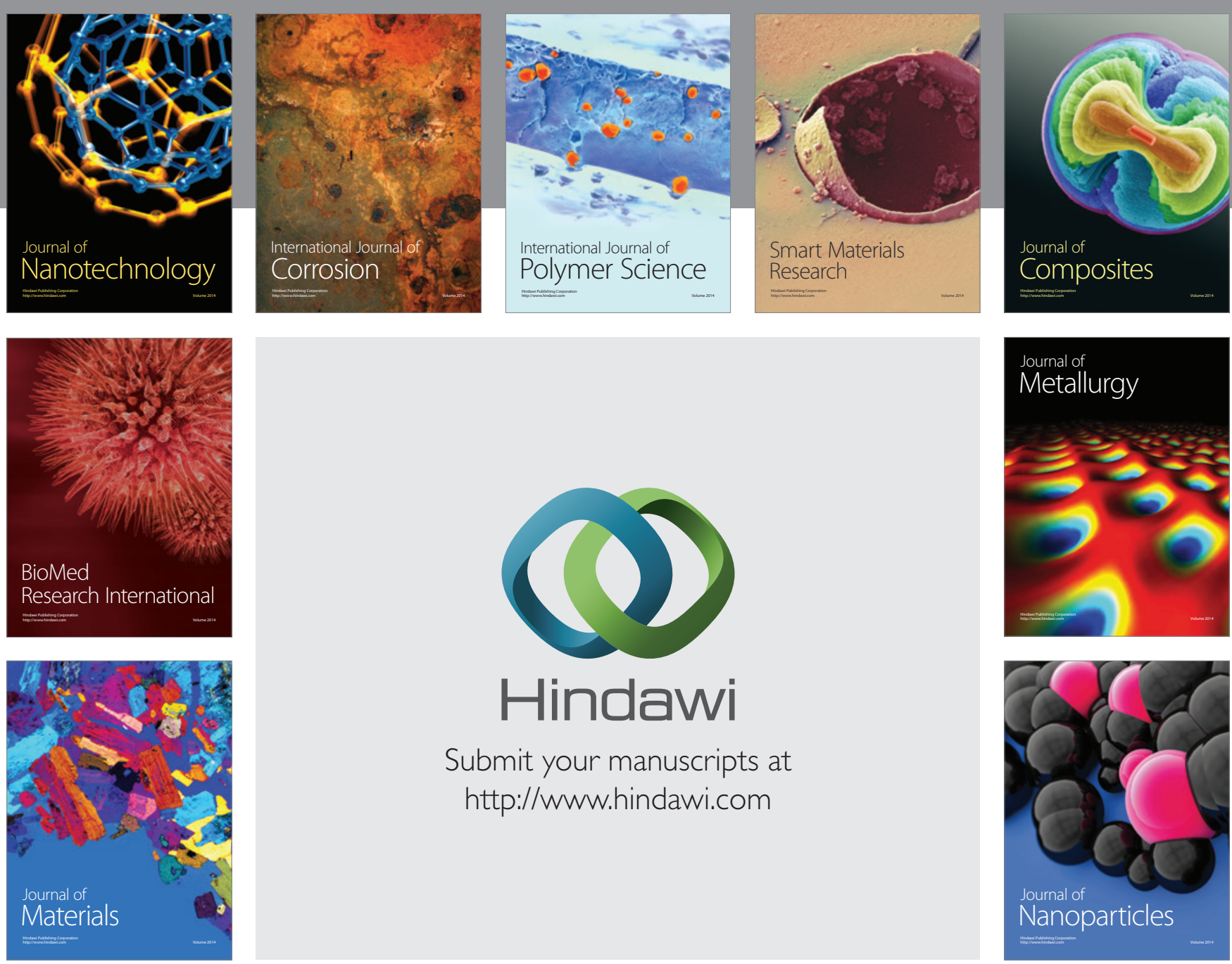

Submit your manuscripts at http://www.hindawi.com
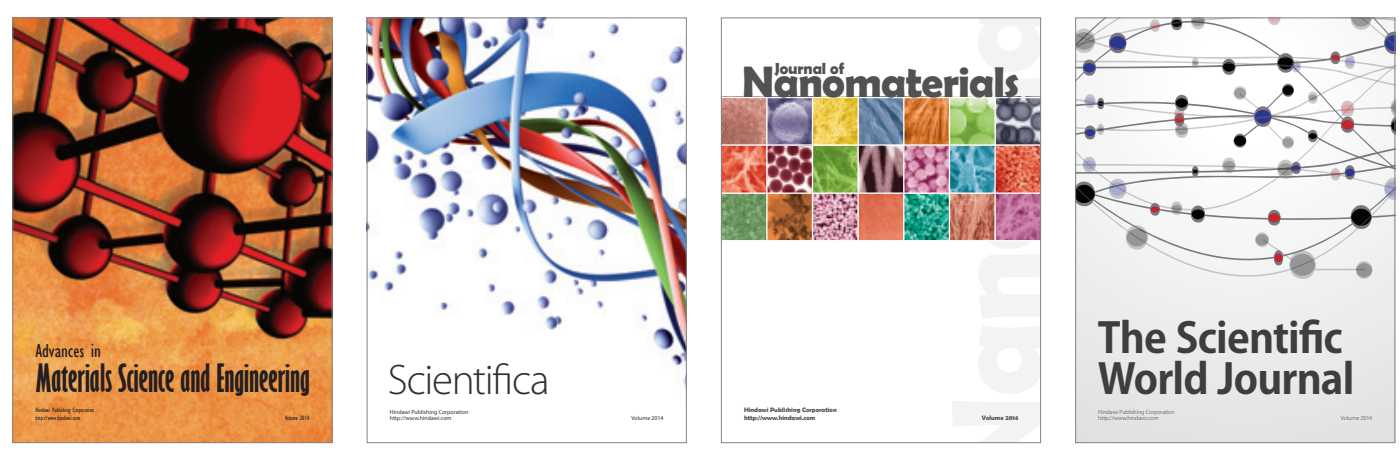

\section{The Scientific World Journal}
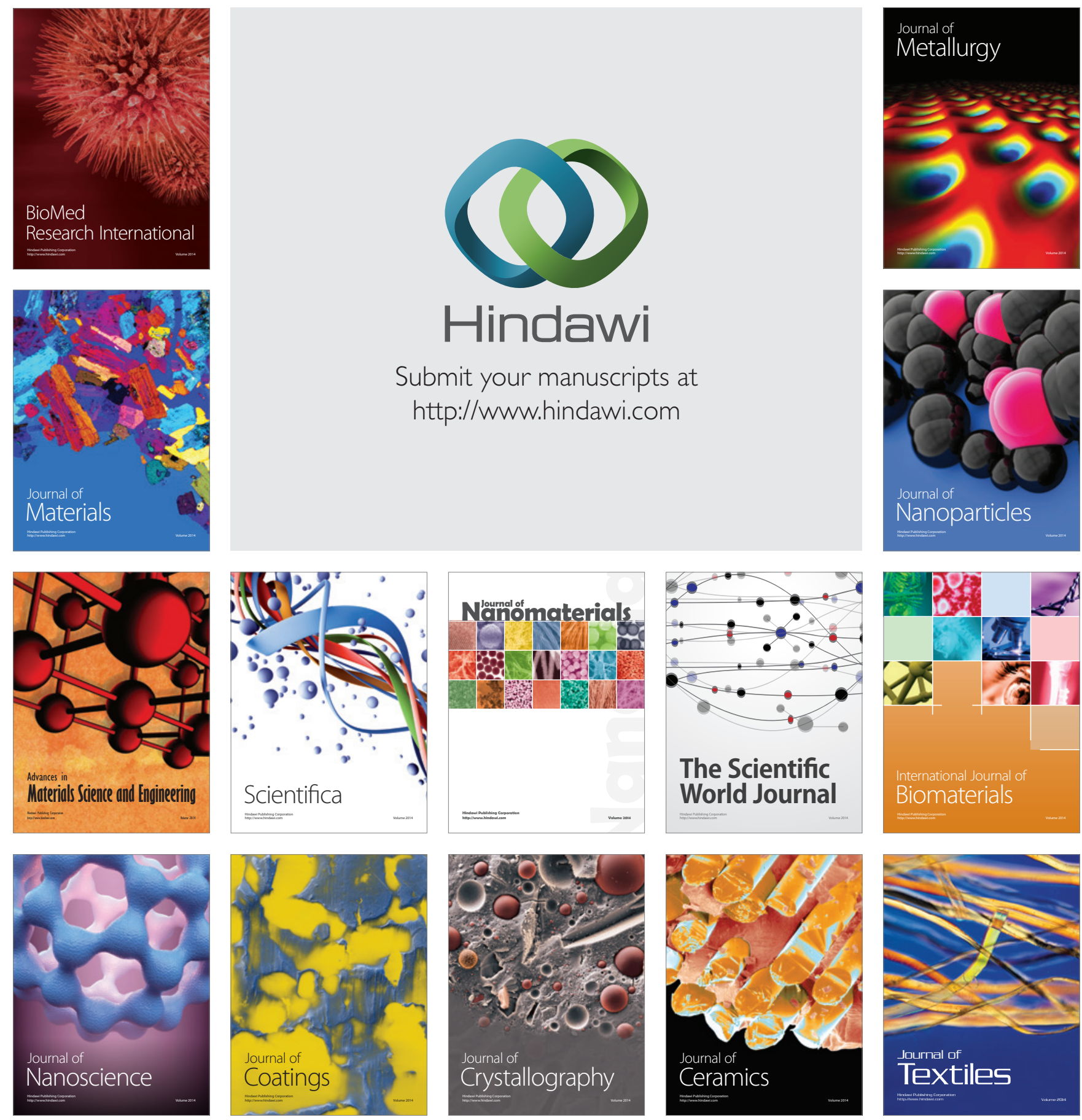